\title{
Article
}

\section{Jean-Jacques Rousseau, Liberty and Counter-Terror Law Since 9/11}

Turner, Ian David

Available at http://clok.uclan.ac.uk/38179/

Turner, Ian David ORCID: 0000-0002-8012-1480 (2021) Jean-Jacques

Rousseau, Liberty and Counter-Terror Law Since 9/11. Keele Law Review, 3 . pp. 20-44. ISSN 2732-5679

It is advisable to refer to the publisher's version if you intend to cite from the work.

For more information about UCLan's research in this area go to

http://www.uclan.ac.uk/researchgroups/ and search for < name of research Group>.

For information about Research generally at UCLan please go to

http://www.uclan.ac.uk/research/

All outputs in CLoK are protected by Intellectual Property Rights law, including Copyright law. Copyright, IPR and Moral Rights for the works on this site are retained by the individual authors and/or other copyright owners. Terms and conditions for use of this material are defined in the policies page.

\section{CLoK}

Central Lancashire online Knowledge www.clok.uclan.ac.uk

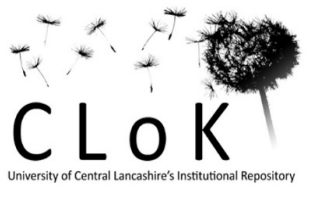




\title{
Jean-Jacques Rousseau, Liberty and Counter- Terror Law Since 9/11
}

\author{
Ian Turner*
}

\begin{abstract}
The international community has struggled to adopt a cohesive response to Islamist terrorism since the late 1990s. Member states of the United Nations have, therefore, been accorded significant discretion in how they react to terror threats. The United Kingdom, for example, has embraced a pro-security agenda in the number of legislative responses it has enacted, together with the breadth of criminalisation these statutes employ. The theory of the social contract is particularly applicable to the difficulties modern countries face in drawing the line between liberty and security. Thomas Hobbes and John Locke traditionally theorise opposing ends of this spectrum. But contemporary security discourse has often overlooked the philosophical contribution of another theorist of the same era as Hobbes and Locke, JeanJacques Rousseau. Where does Rousseau present on the liberty/security divide? Do his writings represent a theoretical model for the UK's pro-security response since 9/11? These are the questions this piece seeks to answer.
\end{abstract}

\section{Introduction}

The reaction of America and many of its allies after 9/11 has been to pass ever more libertyinterfering, counter-terror law. Some countries in the world have preferred not to prosecute terrorism through special laws but have relied on their existing criminal codes. Other countries have enacted counter-terror law, often as an excuse to suppress political dissent. This variation in legislative approach suggests a lack of consensus amongst the international community on how best to comply with their duties in Article 2(1)(e) of United Nations Security Council (UNSC) Resolution 1373, 2001: the obligation on member states of the UN to criminalise the commission and preparation of terrorism in their domestic law. Indeed, it is perhaps unsurprising that a uniform definition of terrorism at international level is lacking. There have been attempts to adopt a more coherent approach to counterterrorism beyond the regional level, ${ }^{1}$ such as the UN Comprehensive Convention Against International Terrorism (2002), but this is still in draft form. ${ }^{2}$ Individual member states such as the United Kingdom (UK) have

*Reader in Human Rights and Security, the School of Justice, the University of Central Lancashire, Preston, UK. Email: idturner@uclan.ac.uk. Twitter: @DrIanTurner. The author is grateful to Steven Greer, Aoife O'Donoghue, Thomas Poole, Brian Rosebury and an anonymous reviewer for providing feedback on earlier drafts of this piece. The author is of course responsible for any errors or omissions.

${ }^{1}$ At regional level, such as in Europe, there is a particularly strong transnational approach to countering terrorism through law, such as in the Council of Europe - the Convention on the Prevention of Terrorism, 2005, and the Additional Protocol to the Council of Europe Convention on the Prevention of Terrorism, 2015 - and the European Union - Directive (EU) 2017/541 of the European Parliament and of the Council, 2017.

${ }^{2}$ Although there is an absence of a unified - legal - definition of terrorism at international level, there are still pockets of coherence in managing particular terror threats such as terrorist 
been afforded much discretion, therefore, in how they pursue and prosecute terrorists. The UK has employed a keen security orientated approach, at the expense of individual liberty, in its legislative responses since $9 / 11$.

Theoretically, the contemporary balance between liberty and security is no better represented for this author than in the social contract philosophy of the Enlightenment, such as that presented by Thomas Hobbes, 1588-1679, and John Locke, 1632-1704. Here, the idea is that individuals depart a 'state of nature' for civil society and sacrifice some, if not all, of their 'natural rights' such as self-preservation in exchange for security provided by a sovereign authority. ${ }^{3}$ But in civil society Hobbes and Locke are traditionally positioned at opposing ends of the divide between security and liberty: one with an absolutist state as a means of collective protection (Hobbes) and another with minimal state power, harking back to the idealistic principles of anarchic freedom individuals had previously enjoyed in the state of nature (Locke). That said, confusingly, Hobbes and Locke are both security theorists; the difference being, the degree to which they conferred power on the state in civil society for communal protection. So, for the purposes of clarification in this piece, the author also labels the Hobbesian - 'security' - end of the liberty/security divide as 'hard security' and the Lockean - 'liberty' - end as 'soft security'.

Thomas Hobbes and John Locke were not the only proponents of Enlightenment social contract theory: there were others such as Jean-Jacques Rousseau, who was born only eight years after Locke's death, in 1712. The approaches of Hobbes and Locke to the social compact are similar: Hobbes vested sovereign power in a body chosen by the majority, but this sovereign was not a party to the original contract; ${ }^{4}$ Locke also vested sovereign power in a body chosen by the

bombings, the financing of terrorism and nuclear terrorism - see: International Convention for the Suppression of Terrorist Bombings, 1997; International Convention for the Suppression of the Financing of Terrorism, 1999; International Convention for the Suppression of Acts of Nuclear Terrorism, 2005, respectively. And, although terrorism is not a separate crime of international concern, for example within the statute of the International Criminal Court, the Rome Statute of the International Criminal Court, 1998, terrorising civilians during armed conflict constituted a war crime at the International Criminal Tribunal for the former Yugoslavia (ICTY) in Prosecutor v. Galic (2003) IT-28-29. Indeed, terrorising civilians during peacetime was found to be a violation of customary international law by the Appeals Chamber of the Special Tribunal for Lebanon (STL) in 2011: Interlocutory Decision on the Applicable Law: Terrorism, Conspiracy, Homicide, Perpetration, Cumulative Charging, Case No. STL11-01/I. On the issue of terrorism and international law more generally, see, for example: Ben Saul (ed), Research Handbook on International Law and Terrorism $2^{\text {nd }}$ ed. (Cheltenham: Edward Elgar Publishing 2020).

${ }^{3}$ In this article the author presents liberty and security as principles in opposition to each other. But of course, they are not mutually exclusive; for example, a famous liberal constitutional theorist, Montesquieu, 1689-1755, noted that (political) liberty can also be guaranteed by security - see: Charles Louis de Secondat, Baron de Montesquieu, The Spirt of Laws (Seattle: Amazon 2015), Book XII, Chapter I, 156.

${ }^{4}$ This claim may not be as categorical as the author presents here. Hobbes was ambiguous about his sovereign, to be fair. On one occasion he describes his commonwealth as united in one person; on another he explicitly distinguishes the commonwealth from the sovereign. For this reason, Steinberger argues: 'From this we can only conclude that the sovereign, as the commonwealth's ultimate organ of decision, is indeed an essential part of and, yet, not at all 
majority, but this sovereign was a party to the original contract. Importantly, Rousseau's sovereign was not detached from its covenantees, the people: it was the people. And in security theory, much less is known about Rousseau within the discourse: where does he present on the balance between liberty/soft security and security/hard security? Does freedom dominate Rousseau's political philosophy and therefore he has much more in common with Locke? Or does security dominate his political philosophy and therefore he has much more in common with Hobbes?

At first glance, positioning Rousseau's position on the divide between liberty and security is much more difficult than doing so for Hobbes and Locke. One of Rousseau's relative contemporaries, Benjamin Constant, 1767-1830, described Rousseau's The Social Contract, published in 1762, as 'the most terrible support of all kinds of despotism' ${ }^{5}$ In the $20^{\text {th }}$ century, Isaiah Berlin, 1909-1997, described Rousseau as 'the most sinister and most formidable enemy of liberty in the whole history of modern thought' ${ }^{6}$ And for Bertrand Russell, 1872-1970, Rousseau is firmly in the illiberal camp: 'Hitler is an outcome of Rousseau.' ${ }^{7}$ The comparisons with the totality of Adolf Hitler's Nazi regime in Germany in the 1930s and 1940s and Rousseau's civil society are numerous; the latter's enforced socialisation of individuals into a set of beliefs supportive of the state is a key allegation. ${ }^{8}$ On the other hand, one of the most authoritative texts on the topic of totalitarianism in the $20^{\text {th }}$ century, Hannah Arendt's The Origins of Totalitarianism, ${ }^{9}$ published in 1951, makes no reference to Rousseau whatsoever. Thus, for Chapman, concern with Rousseau's work as a source of totalitarian doctrine may have obscured its contribution to the theory and practice of liberal democracy. ${ }^{10}$ Indeed, the most famous liberal conceptor of the social contract in recent times, John Rawls, in his $A$ Theory of Justice, first published in 1971, acknowledges the debt he owes to Rousseau. ${ }^{11}$

Contemporary readers should be familiar with the idea of 'terrorism', but this would not have been an identifiable phenomenon to the Enlightenment theorists presented here. It is largely a modern-day concept but of course was originally a French word and has its roots in the French Revolution. ${ }^{12}$ (The French Revolution coincidentally drew on the philosophy of Rousseau as a theoretical model. ${ }^{13}$ ) In its modern conception, the term terrorism is used to represent a harm,

the same as the commonwealth itself.' See: Peter J Steinberger, 'Hobbes, Rousseau and the Modern Conception of the State' 70 (2008) The Journal of Politics, 595-611, 598.

${ }^{5}$ M E Brint, 'Jean-Jacques Rousseau and Benjamin Constant: A Dialogue on Freedom and Tyranny' 47 (1985) The Review of Politics, 323-346, 324.

6 David Lay Williams, 'Modern Theorist of Tyranny? Lessons from Rousseau's System of Checks and Balances' 37 (2005) Polity, 443-465, 444. See also: Stefan Colligan, 'Negative and Positive Liberty and the Freedom to Choose in Isaiah Berlin and Jean-Jacques Rousseau' 12 (2018) The Journal of Philosophical Economics, 36-64.

${ }^{7}$ Bertrand Russell, History of Western Philosophy (London: George Allen and Unwin 1961), 660.

${ }^{8}$ Ian Hampsher-Monk, 'Rousseau and Totalitarianism - with Hindsight?' in Robert Wokler (ed), Rousseau and Liberty (Manchester: Manchester University Press 1995), 267-288, 268.

${ }^{9}$ Hannah Arendt, The Origins of Totalitarianism (London: Penguin Classics 2017).

${ }^{10}$ John W Chapman, Rousseau - Totalitarian or Liberal? (New York: Columbia University Press 1956), vii.

${ }^{11}$ John Rawls, A Theory of Justice (Cambridge: Harvard University Press 1971), 11.

${ }^{12}$ Bruce Hoffman, Inside Terrorism (New York: Columbia University Press 2006), 3.

${ }^{13}$ Robert Wokler, Rousseau: A Very Short Introduction (Oxford: Oxford University Press 
often serious, to effect political change; the ordinary democratic process having been abandoned for violent means to achieve these ends. How would the philosophers examined in this piece have reacted to such an idea? The approach to the social contract presented by John Locke, for example, permitted severance of the contractual bargain entered between the people and the sovereign, when the sovereign had invaded the natural freedoms of its citizens, such as their rights to property, without their consent. For Locke this would have been a legitimate right of revolution to institute a new sovereign for protection (adopted later in the Preamble of the Declaration of the Independence of the United States, in 1776, for example). ${ }^{14}$ But, of course, states often react violently to revolts by citizens, such as the Assad regime in Syria and their recent brutal responses to pro-democracy opponents, labelling them as terrorists. So, Locke arguably would be supportive of 'terrorists' if the ideals of the people were to resist a rights-interfering tyrant. However, Locke's position on this issue may be more ambiguous if individuals' property rights were being infringed to fund collective safety, since he was unclear about how to reconcile the expense of communal security with individuals' refusal to pay taxes to fund it. ${ }^{15}$ Whilst certainly an interesting academic exercise, the aim of this piece is not to investigate the approaches of social contract theorists of the Enlightenment, especially Rousseau, to the ideas of terrorism and examine their relevance to particular aspects of current means to counter insecurity. The objective of this article is, first, to explore Rousseau's model of the social contract and draw conclusions about the extent to which it confers freedom on citizens, if at all, then, uniquely, position this appreciation of the sovereign's power on the divide between liberty/soft security and security/hard security. Following this, as an original contribution to knowledge, the degree to which Rousseau provides a holistic vindication of a broadly-defined legislative regime will be determined. For reasons of word length, the author confines his assessment to the UK's statutory responses since 2001. The purpose of the next section of this piece is, therefore, to analyse counter-terror measures enacted in the UK since $9 / 11^{16}$

\section{The UK's legislative responses to Islamist terrorism since 9/11}

Following Al-Qaeda attacks in Africa in the late 1990s, such as the attacks on the embassies of the United States in Tanzania and Kenya in 1998, the UK converted its previous temporary, emergency legislation, the Prevention of Terrorism (Temporary Provisions) Act 1974, into a permanent statute, the Terrorism Act 2000, to reflect the growing threat from international terrorism. The Terrorism Act 2000 is the source of the UK's wide definition of terrorism, such as only seeking to 'influence' government, ${ }^{17}$ as per s.1, and includes the proscription of terror

2001), 22.

${ }^{14}$ John Locke, Two Treatises of Government (Cambridge: Cambridge University Press 1988), Second Treatise of Government, Chapter XIII, 367.

${ }^{15}$ Russell (n 7) 609.

${ }^{16}$ Indeed, whilst the central premise of the applicability of Rousseau's theory of the social contract in this piece is on the spectrum between liberty and security, as a consequence of continued acts of Islamist terror, the Rousseauian principles found in this work could apply equally to other, more contemporary, threats to global security such as (at the time of writing) covid: United Nations, 'New Social Contract Needed to Combat "Inequality Pandemic": Guterres' 20 July 2020 https://news.un.org/en/story/2020/07/1068721 accessed 23 July 2020.

${ }^{17}$ David Anderson QC, The Terrorism Act in 2013: Report of the Independent Reviewer on the Operation of the Terrorism Act 2000 and Part 1 of the Terrorism Act 2006. 2014 https://assets.publishing.service.gov.uk/government/uploads/system/uploads/attachment_data 
groups, as per s.3; the decision to proscribe a group is made by the executive branch of the state, the Secretary of State for the Home Department. There are criminal offences related to proscription, such as membership of a terror group, but also the mere support for a proscribed organisation, as per ss.11 and 12 respectively.

The Terrorism Act 2000 contains other crimes of a terrorist nature such as possession for terrorist purposes and collection of information, as per ss.57 and 58 respectively. The latter is particularly problematic because of its apparent lack of specificity; ${ }^{18}$ for example, it could include the harmless acquisition of data such as transport enthusiasts' recording of numbers and times of buses, trains, planes etc. The Terrorism Act 2000 also provides for the stop and search of individuals, as per s.43, sometimes without reasonable suspicion, as per s.47A.

Following the Islamist terror attacks in London on the 7 July 2005, the Terrorism Act 2006 was passed, criminalising the encouragement of terrorism, the dissemination of terrorist publications and acts preparatory to terrorism, as per ss.1, 2 and 5 respectively. Encouragement of terrorism and the dissemination of terrorist publications have a chilling effect on free speech. ${ }^{19}$ For example, a person does not need to encourage terrorism (they can do so recklessly); and the risk that an act of terrorism be committed by the encouragement need not be shown. Section 5 does not require a person to have a specific terror plot in preparation, only that they have an intention to commit a harm, within the wide definition of terrorism in the UK, which they have begun to facilitate.

In 2008 the UK passed the Counter-Terrorism Act 2008 permitting, for example, the postcharge questioning of terror suspects, as per s.22, arguably compromising the right to a fair trial. $^{20}$ The statute also introduced 'notification', the equivalent of a sex offenders register for convicted terrorists when they are released from prison, as per s.47, with no consideration for an individual's likelihood of reoffending. ${ }^{21}$ More recent terror attacks occurred in the UK, at the Ariana Grande concert in Manchester in May 2017, and on the London Bridge in June 2017, which precipitated the Counter-Terrorism and Border Security Act 2019. For instance,

/file/335310/IndependentReviewTerrorismReport2014.pdf last accessed 15 November 2020, 27-32.

${ }^{18}$ David Lowe, Terrorism: Law and Policy (Abingdon: Routledge 2018), 61. Indeed, the claim that s.58 of the Terrorism Act 2000 lacked sufficient certainty to be a criminal offence, in contravention of Article 7 of the European Convention on Human Rights (ECHR), no punishment without law, was the subject of litigation, in Jobe v. United Kingdom, Application number 48278/09, before the European Court of Human Rights in Strasbourg. But this argument about a lack of certainty was rejected by the court.

${ }^{19}$ Ian Turner, 'Limits to Terror Speech in the UK and USA: Balancing Freedom of Expression with National Security' [2020] Amicus Curiae, 201-232. https://journals.sas.ac.uk/amicus/article/view/5130 last accessed 19 November 2020.

20 Human Rights Watch, briefing on the Counter-Terrorism Bill 2008 July 2008 https://www.hrw.org/sites/default/files/reports/uk0708web.pdf last accessed 19 November 2020, 10-13.

${ }^{21}$ Human Rights Watch, UK: Counter the Threat or Counterproductive? Commentary on $\begin{array}{llll}\text { Proposed Counterterrorism Measures } & \text { October }\end{array}$ https://www.hrw.org/legacy/backgrounder/eca/uk1007/uk1007web.pdf last accessed 19 November, 20-21. 
this statute makes it a criminal offence to merely view terror material over the internet, as per s.3.

At the time of writing, the terror threat level in the UK is 'substantial', meaning a terror attack is likely. But for the most part since 9/11, the UK's terror threat level has been at its secondhighest level, 'severe', meaning an attack was highly likely. (It was at its highest, 'critical', in 2017 , for example.) Reflecting the average terror threat level since 9/11, 'severe', as well as the raft of counter-terror legislation the UK has passed since 2001, the country's approach to anti-terrorism has been one motivated principally by security concerns. Of course, counterterror law is naturally liberty interfering, but the prevalence of the UK's statutes, preferred to a traditional criminal justice approach, together with the legislative breadth of criminalisation, suggests a particular concentration of power in the state at the (hard) security end of the divide.

However, there are qualifications to the claim that the UK's counter-terror law is very much on the side of the security spectrum. First, for a group to be proscribed by the Secretary of State, they must still be 'concerned in terrorism', as per s. 3(4) of the Terrorism Act 2000; that is, they cannot be proscribed on the mere say-so of the Minister. And there is an opportunity for a group to challenge the Minister's proscription, as per s.4, with further challenges to a Proscribed Organisations Appeals Commission (POAC) and then to the Court of Appeal, as per ss.5 and 6 respectively. And UK counter terror law has had some considerable reform in recent years, in being less security orientated: the reduction in the pre-charge detention period for terror suspects from 28 days in the Terrorism Act 2006 to 14 days in the Protection of Freedoms Act 2012 being an obvious example. Indeed, there was also the reform of the notorious s.44 of the Terrorism Act 2000, the state's power to stop and search individuals at will, following an adverse judgment of the European Court of Human Rights in Strasbourg in Gillan v. United Kingdom. ${ }^{22}$

There has been a raft of counter-terror law in the UK as a direct consequence of 9/11, such as the Anti-Terrorism, Crime and Security Act 2001, in indefinitely detaining international terror suspects, as per s.21. But following an indictment of the measures on human rights grounds by the UK's (then) highest appeal court, the House of Lords, in A v. Secretary of State for the Home Department, ${ }^{23}$ these provisions were replaced by control orders in s. 1 of the Prevention of Terrorism Act (PTA) 2005. The PTA replaced indefinite detention with 'house arrest'. Control orders were themselves replaced by Terrorism Prevention and Investigation Measures (TPIMs) in s.1 of the Terrorism Prevention and Investigation Measures Act 2011. By raising the standard of proof for the imposition of a TPIM from reasonable suspicion for a control order to reasonable belief, as per s.3, there were further attempts to protect liberty. Indeed, the standard of proof for TPIMs was raised still further, to a balance of probabilities, in s.20 of the Counterterrorism and Security Act (CTSA) $2015 .{ }^{24}$ So there have been some liberty gains in

22 [2010] ECHR 28.

23 [2004] UKHL 56; [2005] 2 AC 68.

${ }^{24}$ For an analysis of the UK's various attempts to find the correct balance between liberty and security, in relation to the preventative measures the country has adopted since 9/11, see, for example: Ian Turner, 'The Prevention of Terrorism: in Support of Control Orders, and Beyond' 62(3) (2011) Northern Ireland Legal Quarterly, 335-359; and Ian Turner, 'A Communitarian Justification for Measures to Prevent Terrorism in the UK' 10(5) (2016) Perspectives on Terrorism, 68-82. http://www.terrorismanalysts.com/pt/index.php/pot/article/view/542/html last accessed 19 November 2020. 
areas of UK counter-terror law in recent times away from the (hard) security end of the spectrum. But the country's model of counterterrorism is one still motivated principally by security concerns, reflective of the (hard) security side of the divide. Which theoretical approaches to security would support this concentration of power in the state? This is the aim of the next section where, to inform later assessments of Rousseau, security models of traditional theorists such as Thomas Hobbes and John Locke are briefly examined.

\section{The social contract of Hobbes and Locke}

The theory of the social contact is particularly relevant to contemporary discussions about the degree to which individual liberty is sacrificed in pursuit of collective security, post 9/11. Of these social contract theorists, Thomas Hobbes and John Locke are especially important. Thomas Hobbes, for example, is famous for instituting an absolute sovereign power; because of the horrors and lawlessness of the English Civil War, 1642-1651, which Hobbes witnessed during his lifetime, any government, even a bad one, was better than no government. ${ }^{25}$

For his social contract, to leave the chaos of pre-civil society, the 'state of nature', Hobbes envisaged individuals would first covenant between themselves, whereby they would all agree to organise themselves into a 'Common-wealth'. ${ }^{26}$ There would then be a second, authorising covenant where the commonwealth agreed to obey a sovereign chosen by the majority, ${ }^{27}$ whose purpose was to provide collective protection. The citizen's duty of obedience to the sovereign was indefinite. ${ }^{28}$ To fulfil the responsibility of security, absolute power was vested in the sovereign, ${ }^{29}$ who had no terrestrial equal: 'The Sovereign Power...render an account thereof to God... and to none but him. ${ }^{30}$ So one contemporary model of protection from Islamist terrorism post 9/11, according to Hobbes, would be for the complete sacrifice of individual liberty for the maintenance of (hard) security by the state. ${ }^{31}$

${ }^{25}$ Thomas Hobbes, Leviathan (Cambridge: Cambridge University Press 1996), Chapter XVIII, 128.

${ }^{26}$ Thomas Hobbes, Human Nature and De Corporo Politico (Oxford: Oxford University Press 1994), Chapter XX, 112.

27 Thomas Hobbes, Man and Citizen (De Homine and De Cive) (Indianapolis: Hackett Publishing Company 1998), De Cive, Chapter VII, 192.

${ }^{28}$ Hobbes (n 25) Chapter XV, 100.

${ }^{29}$ Ibid., Chapter XVII, 120. But is it right to categorise Hobbes as a state absolutist, at least in the strict sense? For a contrary view, see, for example, Eleanor Curran, 'Blinded by the Light of Hohfeld: Hobbes's Notion of Liberty' (2010) 1 Jurisprudence 85-194; and Ian Turner, 'Conceptualising a Protection of Liberal Constitutionalism Post 9/11: an Emphasis Upon Rights in the Social Contract Philosophy of Thomas Hobbes' (2020) 24 International Journal of Human Rights 1475-1498.

${ }^{30}$ Ibid., Chapter XXX, 231.

${ }^{31}$ In condoning an absolutist state, Hobbes failed to foresee concerns, later expressed by constitutional scholars, such as Montesquieu, that the state itself might pose a threat to security - see: de Secondat, Baron de Montesquieu (n 3) Book XI, Chapter IV, 136. To prevent abuse, Montesquieu famously called for a separation of governmental powers, in Book XI, Chapter VI, 137: 'When the legislative and executive powers are united in the same person... there can be no liberty...Again, there is no liberty if the judiciary power be not separated from the legislative and executive. Were it joined with the legislative, the life and liberty of the subject would be exposed to arbitrary control; for the judge will be then the legislator. Were it joined 
For John Locke, individuals exited pre-civil society, the state of a nature, by joining together in a commonwealth, too. This was also an original compact with everyone's consent. ${ }^{32}$ And the commonwealth acted as one body with the power to determine for the majority. ${ }^{33}$ Unlike Hobbes, however, the commonwealth then covenanted directly with a sovereign, to provide collective security. ${ }^{34}$ Locke was far more freedom orientated than Hobbes (at least after the transition to civil society). Locke is considered a classical liberal or a 'libertarian': ${ }^{35}$ the sovereign is instituted for minimal protection, such as for military and civil defence, to secure individuals' natural rights to life, liberty and estate, especially property. ${ }^{36}$ Thus, Locke believed that the power of the state was limited, to the 'Peace, Safety, and [the] public good of the People'. ${ }^{37}$ The state had 'no other end but preservation' and, thus, could not 'destroy, enslave, or designedly...impoverish the subjects. ${ }^{, 38}$ So, unlike Hobbes, Locke's approach to the social contract imposed significant limitations on the sovereign. Therefore, at the freedom end of the liberty/security spectrum, Locke's writings are surely incompatible with the ever-increasing liberty-interfering counter-terror legislation in the UK since 2001.

Security theory has traditionally drawn on the social contract absolutist Thomas Hobbes and the social contract libertarian John Locke. These Enlightenment philosophers provide modern scholars with rich perspectives on the degree to which freedom must be sacrificed to maintain the state's covenant of protection, particularly following 9/11. A natural consequence of this, however, has been to assess contemporary challenges to security only from a Hobbes versus Locke - 'binary' - perspective. Interestingly, where is Jean-Jacques Rousseau, 1712-1778, an equally famous social contract theorist of the Enlightenment era, but overlooked in security discourse, located on the same liberty/security spectrum?

\section{Social Contract}

to the executive power, the judge might behave with violence and oppression. There would be an end of everything, were the same man, or the same body...to exercise those three powers, that of enacting laws, that of executing the public resolutions, and of trying the causes of individuals.'

${ }^{32}$ Locke (n 14) Second Treatise of Government, Chapter VIII, 331.

${ }^{33}$ Ibid.

${ }^{34}$ Ibid., Chapter XIX, 428.

${ }^{35}$ The term libertarian is a modern concept so is not a label that would have been familiar to Locke. (Indeed, even the term 'liberal' was not first used until about the beginning of the $19^{\text {th }}$ Century - see: Juliet A Williams, Liberalism and the Limits of Power (New York: Palgrave Macmillan 2005) 3-4.) But later, noted libertarians, such as Robert Nozick - see, for example: Robert Nozick, Anarchy, State and Utopia (New York: Basic Books 1974) - have described Locke as a libertarian, since, for Locke, the state was not permitted to violate an individual's right to property for the common good without their consent. But was Locke such a lover of individual freedom since, in The Fundamental Constitutions of Carolina (1669), he legitimised slavery, in Article 110? 'Every freeman of Carolina shall have absolute power and authority over his negro slaves, of what opinion or religion' - see: John Locke, Political Essays (Cambridge: Cambridge University Press 1997), 160-181, 175.

${ }^{36}$ Locke (n 14) Second Treatise of Government, Chapter IX, 350-351.

${ }^{37}$ Ibid., Chapter IX, 353.

${ }^{38}$ Ibid., Chapter XI, 357. 
Jean-Jacques Rousseau shared a similar idealised view of the state of nature as John Locke. ${ }^{39}$ Like Locke (and indeed Hobbes), Rousseau's approach to the state of nature was influenced by the freedom it conferred on the individual. In one of his earlier works, A Discourse on Inequality, which was first published in 1754 , the natural person had free will; ${ }^{40}$ they had anarchic freedom, since by definition the state of nature was a condition where there was no government and no positive law; ${ }^{41}$ and they had personal freedom, since they were not dependent on a master, an employer, an immediate superior for their livelihood. ${ }^{42}$ But for Rousseau this was the 'original' state of nature. Thus, in his later work, The Social Contract, for example, when he described the state of nature as 'an uncertain and precarious mode of existence', ${ }^{43}$ Rousseau was depicting the 'social' or 'pre-political' state of nature, not the 'original' one.

In addition to natural freedoms, an important principle for Rousseau in the state of nature was equality. ${ }^{44}$ Naturally, there were two forms of inequality: the first was 'physical', arising from differences in 'age, strength of the body and qualities of the mind or soul'; 45 the second was 'moral or political inequality'. The latter consisted of the 'different privileges which some enjoy to the prejudice of others - such as their being richer, more honoured, more powerful than others' ${ }^{46}$ This inequality - the desire to be better than others and the desire to be esteemed by others - developed in the pre-civil society. These evils were the main effects of private property. ${ }^{47}$ The differences in individuals' financial capacities and in their circumstances produced an even greater inequality in their conditions, which in turn led to a war between each and all. It was, therefore, in Rousseau's later work, The Social Contract, that it was only after the introduction of civil society, where everything was under the authority of positive laws, that society returned to the peace and prosperity of its members. ${ }^{48}$

In the state of nature Rousseau was committed to individual freedom. And, like Hobbes and Locke, for Rousseau, there were the natural rights of humans such as self-preservation. Since a person was their own master, slavery was also contrary to nature, permitting, therefore, a person a natural freedom from slavery. ${ }^{49}$ Like Locke, Rousseau also believed in the 'essential gifts of nature, such as life and liberty' ${ }^{50}$ and of which it was 'at least doubtful whether anyone

39 Jean-Jacques Rousseau, 'A Discourse on the Sciences and the Arts' in Jean-Jacques Rousseau, The Basic Political Writings (Indianapolis: Hackett Publishing Company 1987), 1$21,14$.

${ }^{40}$ Maurice Cranston, 'Introduction', to Jean-Jacques Rousseau, A Discourse on Inequality (London: Penguin Classics 1984), 9-53, 31.

${ }^{41}$ Ibid., 32.

${ }^{42}$ Ibid.

${ }^{43}$ Jean-Jacques Rousseau, The Social Contract (Ware: Wordsworth Editions 1998), Book II, Chapter IV, 33.

${ }^{44}$ Ibid., 6.

${ }^{45}$ Rousseau (n 40) 77.

${ }^{46}$ Ibid.

${ }^{47}$ Ibid., 119.

${ }^{48}$ Rousseau (n 43) Book I, Chapter IV, 10-11 and Book III, Chapter IX, 84.

${ }^{49}$ Jean-Jacques Rousseau, 'A Discourse on Political Economy' in Rousseau (n 39) 111-138, 112.

${ }^{50}$ Rousseau (n 40) 128. 
has the right to divest himself' ${ }^{51}$ Rousseau also presented the natural right to freedom from want, since it was manifestly contrary to the law of nature that 'a handful of people should gorge themselves with superfluities while the hungry multitude goes in want of necessities'. ${ }^{52}$

Rousseau extoled the virtues of a civil society, following the chaotic inequality of the prepolitical state of nature caused by the ownership of private property. Similar to Locke, there was a challenge of maintaining collective protection, but at the same time retaining freedoms individuals had previously enjoyed in the state of nature. ${ }^{53}$ Rousseau believed this basic problem was solved by 'the total alienation of each associate, together with all his rights, to the whole community'. ${ }^{54}$ This included the relinquishment of all of a person's possessions. ${ }^{55}$ Rousseau acknowledged that this alienation was 'drastic. ${ }^{, 56}$ But individuals were making an advantageous exchange: trading in an uncertain and precarious way of living for one that was better and more secure; of natural independence for civil liberty; the power to harm others for security for themselves; and their strength, which others might overcome, for a right that a social union made invincible.$^{57}$ Indeed, in each individual giving themselves entirely, what was happening for any one individual was the same as what was happening for others. ${ }^{58}$

It will be recalled that Hobbes and Locke envisaged the sovereign as a separate entity to the commonwealth. In the Hobbesian sense the commonwealth covenanted with itself to obey a sovereign chosen by the majority; for Locke, there was a direct covenant of protection between the sovereign and the commonwealth. For Rousseau, however, the sovereign was the body politic, the commonwealth; the sovereign was not the government but the community in its collective - and legislative - capacity. ${ }^{59}$ (The government was a separate body.) Rousseau termed an institution of the state the Legislator. Its function, which was temporary, was to assist with community formation and, confusingly, had no law-making power. ${ }^{60}$ The Legislator was the engineer who invented the machine; they were the constitution maker. ${ }^{61}$

\section{Rousseau's absolutist state?}

In plotting Rousseau on the liberty/security divide, the total alienation of a person's rights, together with all their possessions, to the whole community represents a significant concentration of power in the state, akin to the Hobbesian sovereign. In fact, there is more to suggest confirmation of Rousseau's absolutist status, such as the proscription of public communication about an expression of the 'general will', at least prior to collective discussions. In A Discourse on Political Economy, first published in 1755, Rousseau described the sovereign thus: 'The body politic...is... a moral being which possesses a will; and this general will, which...is the source of the laws, is for all the members of the state, in their relations both

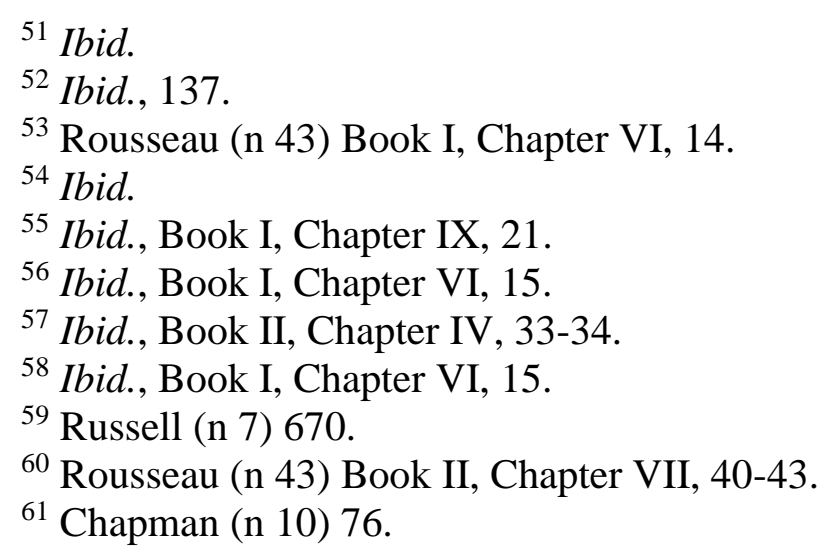


to one another and the state. ${ }^{, 62}$ The general will, which was the most fundamental rule of state, ${ }^{63}$ was a strange and significant concept. It was not an expression of the will of the majority, or even the will of all citizens: it was conceived as the will belonging to the body politic. ${ }^{64}$ 'If the populace held its deliberations (on the basis of adequate information) without the citizens communicating with one another, what emerged from all the little particular wills would always be the general will, and the decision would always be good. ${ }^{65}$ Rousseau, therefore, discouraged prior communication between citizens because this would likely result in an expression of a particular will, not the general will. ${ }^{66}$ So it was important that that each citizen should think only their own thoughts, ${ }^{67}$ after being adequately informed.

Furthermore, Rousseau did not fetter the sovereign. The law was not entrenched: there was no basic law that was binding on the sovereign, even its founding rules. ${ }^{68}$ To limit the sovereign in this way, was to destroy it; binding itself to obey a superior would be a return to the state of nature. ${ }^{69}$ Thus, sovereignty was inalienable ${ }^{70}$ and indivisible. ${ }^{71}$ Indeed, although supremacy was vested in the people, with no apparent checks and balances, there was the real possibility of the tyranny of the majority. ${ }^{72}$

Continuing the apparent totality of the Rousseauian state more broadly, concern is expressed about the Legislator. This is one of the most controversial features of Rousseau's entire political theory. ${ }^{73}$ (The Legislator was the constitution maker; it will be recalled.) Indeed, for some, the Legislator is considered to be a 'totalitarian manipulator' ${ }^{74}$ This allegation originates from Rousseau's conviction that the people did not have sufficient grasp of political principles to enable them to establish a sound constitution by themselves. ${ }^{75}$

\footnotetext{
${ }^{62}$ Rousseau, 'A Discourse on Political Economy' in Rousseau (n 39) 111-138, 114.

${ }^{63}$ Ibid., 111-138, 116.

${ }^{64}$ Russell (n 7) 672.
}

${ }^{65}$ Rousseau (n 43) Book II, Chapter III, 29. Interestingly, Rousseau was vague about the meaning of the general will, suggesting confusion and contradiction - see, for example: Christopher Bertram, Rousseau and the Social Contract (London: Routledge 2004), 98. Williams also acknowledges uncertainty surrounding Rousseau's definition of the general will, but in Rousseau's defence, Williams suggests the concept was never defined precisely because the term was maybe well known to Rousseau's audience at the time - see: David Lay Williams, Rousseau's Social Contract: An Introduction (Cambridge: Cambridge University Press 2014), 245.

${ }^{66}$ Ibid., Book II, Chapter III, 29-30.

${ }^{67}$ Ibid., 30.

${ }^{68}$ Ibid., Book I, Chapter VII, 17.

${ }^{69}$ Ibid., Book IV, Chapter VII, 127.

${ }^{70}$ Ibid., Book II, Chapter I, 25.

${ }^{71}$ Ibid., Book II, Chapter II, 27.

${ }^{72}$ Bertram (n 65) 193.

${ }^{73}$ Lee Ward, Modern Democracy and the Theological Political Problem in Spinoza, Rousseau and Jefferson (New York: Palgrave Macmillan 2014), 87-88.

${ }^{74}$ Philip J. Kain, 'Rousseau, the General Will, and Individual Liberty' 7(3) (1990) History of Philosophy Quarterly, 315-334, 315.

${ }^{75}$ Chapman explains: '[The people] are at the mercy of destructive social processes, the inertia of which is so great that only a striking personality who has their confidence can put the general will into operation' - see: Chapman (n 10) 76. 
In The Social Contract, there is also a chapter on the 'Dictatorship' ${ }^{76}$ Here, Rousseau discussed the inflexibility of laws which prevented them from being adapted to emergencies. Countless things could happen that the state had not provided for; it could not foresee everything. Depending on the nature of the danger, there were two ways an emergency could be managed. If the trouble could be fixed by increasing the government's activity, power was concentrated in the hands of one or two of its members. In this case the change was not in the authority of the laws but only in the form of administering them. But if the peril was of such a kind that the apparatus of the laws was an obstacle to saving the laws, the method was to nominate a supreme ruler who was to silence all the laws and briefly suspend the sovereign authority. ${ }^{77}$

Moving away from the concentration of power in the state, the (limited?) liberty of the individual is now considered. First, with the legislative supremacy of the sovereign, the natural and civil freedoms of citizens were not entrenched. ${ }^{78}$ And, in addition to the discouraging of public communication prior to collective discussions of the general will, Rousseau proscribed 'factions, partial associations', because of the risk that the interests of groups would not correspond with that of the general will. ${ }^{79}$ Freedom of expression and thought were also circumscribed by the office of a public censor. ${ }^{80}$ And there was the prescription of a civic religion. This caused the most public outcry upon The Social Contract's first publication in $1762:{ }^{81}$ it was considered blasphemous to call for a civil religion. ${ }^{82}$ The content of the civic religion was to be fixed by the sovereign. ${ }^{83}$ And whilst the sovereign could not compel anyone to believe the religion and its teachings, it could banish from the state anyone who did not believe them. ${ }^{84}$ (Exceptionally, the death penalty could be imposed on detractors. ${ }^{85}$ ) Thus, Karant questions: 'How does a model...so swiftly descend into a platform of forced exile and [capital] punishment? Can a truly democratic society exclude any of its members particularly atheists? ${ }^{86}$

Each individual, as a member of the state, had a commitment to the sovereign; and as a member of the sovereign, they had a commitment to each of the other individuals, they being one of them. ${ }^{87}$ Any service a citizen could give to the state should be performed as soon as the sovereign demanded it. ${ }^{88}$ Furthermore, Rousseau anticipated situations where individuals may act selfishly, contrary to the general will, such as wishing to pay less taxes, but still expect to benefit from the common good. In this instance the individual would be constrained from

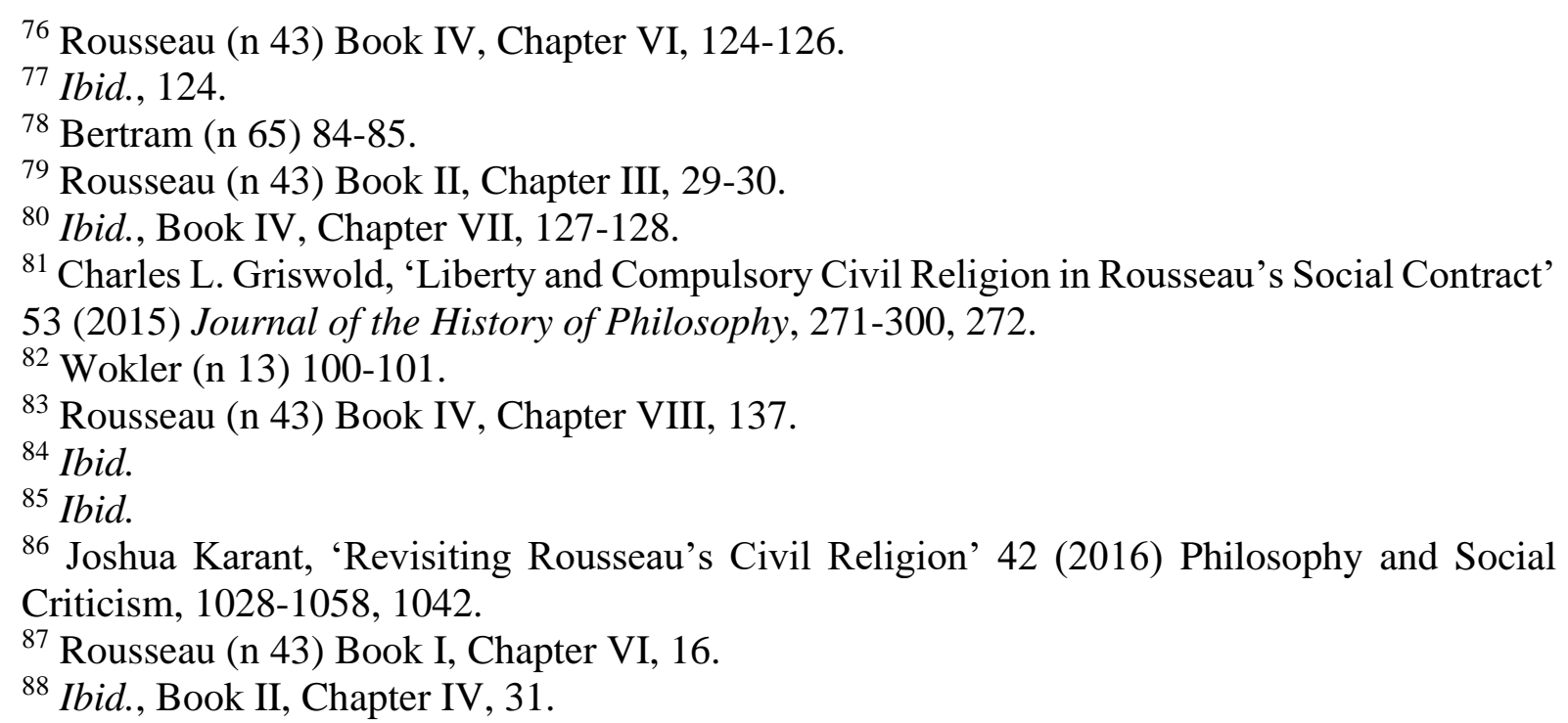


disobeying the general will; chillingly, Rousseau described this practice as forcing the citizens to be free. ${ }^{89}$

The sovereign for Rousseau demanded the complete abrogation of an individual's rights and possessions to it. There were no constitutional limits placed on the sovereign's power; even the original social contract did not bind it. Sovereignty was inalienable and indivisible. And, because of the risk of a subversion of the general will, factions and partial associations were banned. The sovereign prescribed a civic religion, concentrating power in the state apparatus still further. Like factions and partial associations, to avoid selfish behaviour, individuals were compelled to obey the general will - they were forced to be free - and provide the services imposed upon them by the sovereign when asked to do so. Post 9/11, therefore, Rousseau's provisional status on the liberty versus security divide is surely at the upper end of security, where Hobbes is similarly located. But was the state for Rousseau really totalitarian and therefore anti-liberty? because he famously believed that his approach to sovereignty was the complete opposite to tyranny: tyranny necessarily existed wherever the government and populous had different interests and consequently opposing wills. ${ }^{90}$ A consideration of Rousseau's constitutionalism and respect for liberty is considered in the next section.

\section{Rousseau's liberal constitutionalism?}

First, for Rousseau, membership of the new, civil society was voluntary; individuals were not, therefore, coerced into accepting the terms of the original covenant (though if they refused, they then become aliens of the community and, more importantly, were denied sovereign protection). In A Discourse on Political Economy, Rousseau also described sovereignty thus: 'The body politic...is... a moral being which possesses a will; and this general will...always tends toward the conservation and well-being of the whole and of each part..." ${ }^{91}$ So, presumably, there were limitations imposed on the sovereign's power, in, for example, constraining it from acting contrary to the conservation and well-being of the community? Moreover, in noting above that any service a citizen could give to the state should be performed as soon as the sovereign demanded it, Rousseau did qualify this: the sovereign on its side could not impose upon its citizens any services that were useless to the community. ${ }^{92}$ Similarly, there was a not a total abrogation of every person and their possessions to the sovereign: individuals alienated only the part of their powers, goods and liberty that were important for the community to control. ${ }^{93}$ (But the sovereign was the sole judge of what was important. ${ }^{94}$ ) In addition, as the sovereign was made out of nothing but its constituent individuals, it was impossible for the sovereign to injure its citizens. ${ }^{95}$ Sovereignty being invested in the people is an important consideration. In this respect, therefore, according to Cranston, Rousseau was going a good deal further than liberal theorists such as John Locke, who associated freedom with the people's

\footnotetext{
${ }^{89}$ Ibid., Book I, Chapter VII, 18.

${ }^{90}$ Jean-Jacques Rousseau, 'A Discourse on Political Economy' in Rousseau (n 39) 111-138, 116.

${ }^{91}$ Ibid., 114.

92 Rousseau (n 43) Book II, Chapter IV, 31.

93 Ibid.

${ }^{94}$ On this Chapman describes: 'Individuals rights' are dissolved in a vague utilitarianism, the scope of which is left for the sovereign to define.' See: Chapman (n 10) 84.

${ }^{95}$ Rousseau (n 43) Book I, Chapter VII, 18.
} 
consent to obey a constitutional monarch in whom they invested sovereignty. For Rousseau, there was no investment or transfer of sovereignty: sovereignty not only originated in the people, but it also stayed there. ${ }^{96}$

The sovereign was the source of law, it will be recalled. So, laws were self-imposed, as the sovereign was the people assembled; it was therefore impossible for the sovereign to pass unjust laws. ${ }^{97}$ Similarly, legislation was restricted to only matters of 'common concern'. This forced citizens to limit their pursuit of personal good out of regard for the personal goods of others. ${ }^{98}$ And the law also applied to everyone equally, so no one was outside or above it (except the sovereign itself, of course) ${ }^{99}$ Finally, with collective participation in the making of laws, for Barry, this was freedom in a Rousseauian sense: 'Freedom does not consist in protection of the law (guaranteeing a private sphere) but in the opportunities the social contract allows for participation in the making of the law. ${ }^{, 100}$

In reference to the traditional principle of the separation of powers, ${ }^{101}$ in the Rousseauian state there was not a fused constitution with legislative, administrative and judicial powers vested only in the sovereign. ${ }^{102}$ Indeed, in drafting a constitution for Poland, Considerations on the Government of Poland, dating from 1772, Rousseau remarked that one of the existing vices of the Polish constitution was that it had failed to distinguish sufficiently clearly between legislation and administration. ${ }^{103}$ For Rousseau, therefore, the government was distinct from and subordinate to - the legislature. It was equally important that the separation of governmental functions was observed by the sovereign. ${ }^{104}$ Indeed, Rousseau specifically excluded acts of war and peace from the legislative, conferring these powers on the administrative branch of the state, ${ }^{105}$ thus emphasising the separation of the sovereign from the executive still further. In regards to the interpretation of the law, whilst Rousseau did note that whoever made a law knew better than anyone else how it should be interpreted and applied, ${ }^{106}$ the courts should be separate from the sovereign. Indeed, in describing the role of the courts, Rousseau stipulated that judges should be 'beyond reproach' and possess 'all attentiveness and integrity which their position demands'. ${ }^{107}$

\footnotetext{
${ }^{96}$ Maurice Cranston, 'Rousseau's Theory of Liberty', in Wokler (n 8) 231-245, 238.

${ }^{97}$ Rousseau (n 43) Book II, Chapter VI, 38.

${ }^{98}$ Chapman (n 10) 47-48.

99 James Tully, 'Introduction' in Jean-Jacques Rousseau, The Social Contract and Other Later Political Writings (Cambridge: Cambridge University Press 2018), x-xxxix, xx.

${ }^{100}$ Norman Barry, 'Hume, Smith and Rousseau on Freedom' in Wokler (n 8) 27-51, 45.

${ }^{101}$ See, for example: de Secondat, Baron de Montesquieu (n 3) Book XI, Chapter IV, 136.

102 Rousseau (n 43) Book II, Chapter IV, 67.

103 Jean-Jacques Rousseau, 'Considerations on the Government of Poland and on its Projected Reformation' in Rousseau (n 99), 181-265, 221. Indeed, Rousseau did not advocate one particular form of government; he was extremely flexible. He recognized conditions under which democracy, aristocracy, and monarchy might all flourish - see: Williams (n 6) 456. Thus, Rousseau did not automatically concentrate executive power in only one person, such as a Monarchy.

${ }^{104}$ John Hope Mason, 'Forced to be Free' in Wokler (n 8) 121-138, 130.

${ }^{105}$ Rousseau (n 43) Book II, Chapter II, 27.

${ }^{106}$ Ibid., Book II, Chapter IV, 67.

${ }^{107}$ Rousseau (n 99) 181-265, 226.
} 
Continuing the theme of the separation of powers, the Rule of Law has many definitions such as equality before the law, legal certainty, accessibility to the courts, a prohibition on retrospective law making etc. ${ }^{108}$ A principal feature of the Rule of Law is the 'legality principle', that is, government according to law. ${ }^{109}$ Whilst the sovereign was above the law, the executive was not: 'If the nobility or the military or some other order within the state [were to disobey the law]... everything would be irretrievably lost', ${ }^{110}$ and would be a return to the state of nature. ${ }^{111}$ Fidelity to the supremacy of law was no more apparent than in one of Rousseau's later major works, Letters from the Mountain, dating from 1764:

'When each does what he pleases, he often does what displeases others, and that is not called a free state. Liberty consists less in doing one's will than in not being subject to someone else's...Thus there is no liberty without laws, nor where someone is above the Laws: in the very state of nature man is free only under cover of the natural Law that commands everyone. ${ }^{, 12}$

Interestingly, whilst Rousseau held individual freedom in the original state of nature in high regard, it was still subject to (natural) law. On the Rule of Law more broadly, Rousseau was opposed to arbitrary law; the sovereign was incapable of passing unjust law, it was stated above. And laws should be stable. ${ }^{113}$ Rousseau also favoured a limited number of clear and simple laws, ${ }^{114}$ leaving judges to interpret and amplify the laws 'by the natural rights of uprightness and good sense'. ${ }^{115}$ In addition, no law should ever be allowed to fall into decline; it should either be formally repealed or enforced vigorously. ${ }^{116}$

Moreover, protections against the abuse of power by the executive branch were built into the state's constitutional rules, in the institution of a periodical assembly of the people. In enhancing the accountability of the government to the sovereign, at these periodical meetings the authority of the government was automatically suspended and the people sat in judgement on it. ${ }^{117}$ (These periodical assemblies even gave the populace the opportunity to reassert the authority of the sovereign. ${ }^{118}$ )

\footnotetext{
${ }^{108}$ See, for example, Joseph Raz, The Authority of Law: Essays on Law and Morality (Oxford: Oxford University Press 1997), especially chapter 11.

${ }^{109}$ Entick v. Carrington [1765] EWHC KB J98.

110 Jean-Jacques Rousseau, 'A Discourse on Political Economy' in Rousseau (n 39) 111-138, 117.

111 Jean-Jacques Rousseau, 'Principles of the Right of War' in Rousseau (n 99) 166-180, 173.

112 Jean-Jacques Rousseau, Letters from the Mountain in Jean-Jacques Rousseau, Letter to Beaumont, Letters from the Mountain, and Related Writings (Lebanon: Dartmouth College Press 2001), 132-306, 260-261.

${ }^{113}$ Rousseau (n 40) 60.

114 Jean-Jacques Rousseau, 'A Discourse on Political Economy' in Rousseau (n 39) 111-138, 118.

115 Jean-Jacques Rousseau, 'Considerations on the Government of Poland and on its Projected Reformation' in Rousseau (n 99) 181-265, 226.

${ }^{116}$ Ibid., 228.

${ }^{117}$ Chapman (n 10) 51-52.

${ }^{118}$ Steinberger (n 4) 604.
} 
It will be recalled that the Legislator was the architect of the constitutional system of the new civil society. This excluded the collective input of the body politic because Rousseau believed that the citizenry was ill-equipped to decide the society's foundations. This suggests a substantial concentration of power in this state body. However, Kain implicitly disagrees:

'The Legislator is not an outcome of Rousseau's totalitarianism but of his utopianism. The Legislator, who is neither...the government nor the sovereign, must give laws to primitive people who is unable to give them to itself. The Legislator gives laws, not in a sense of particular laws - these can only arise from the general will - but in the sense of a general political constitution and of the conditions necessary for the realisation of the general will - which nevertheless must still be approved by the people.' 119

Furthermore, in regards to Rousseau's dictatorship, the triggering of the body's emergency powers was tightly circumscribed: only the greatest dangers could outweigh that of changing the public order; the primary intention of the dictatorship was that the state should not perish. ${ }^{120}$ Even Locke permitted the legislative to act outside the law, or even against it, in times of emergency to protect the existing order. The exercise of the power, for Locke, was never to be questioned. ${ }^{121}$ To prevent abuse, Rousseau fixed the dictatorship for a very short term, maybe six months, and it could never be prolonged. Sovereign authority was only suspended; the dictator did not have the power to pass laws. ${ }^{122}$

Rousseau also attended to a perennial question within social contract theory: fidelity to the original compact. A common criticism of Hobbes, for example, was his faith that all the individuals in the commonwealth would keep to their promises of obeying the sovereign authority, if it turned out to be to their advantage later to break it. ${ }^{123}$ Others have questioned

${ }^{119}$ Kain (n 74) 330.

${ }^{120}$ Rousseau (43) Book IV, Chapter VI, 124.

${ }^{121}$ Locke (n 14) Chapter XIII, 373-375. And Montesquieu permitted a limited suspension of constitutional arrangements for a society's self-preservation: 'But, should the legislature think itself in danger, by some secret conspiracy against the state, or by some correspondence with a foreign enemy, it might authorise the executive power, for a short and limited time, to imprison suspected persons, who in that case, would lose their liberty only for a while, to preserve it forever.' See: de Secondat, Baron de Montesquieu (n 3) Book XI, Chapter VI, 138.

122 Rousseau (n 43) Book IV, Chapter VI, 126. Indeed, more modern commentators on this issue, for example, such as Carl Schmitt, 1888-1985, did not impose a time limit on their dictator, in his work Dictatorship, dating from 1921. At the time Schmitt was seeking to protect the Weimar Republic in Germany after World War I from factions on the Left and Right seeking to destroy it. Schmitt described Rousseau's dictator, to manage a crisis and relinquish power after the crisis had been averted, as a 'commissarial' dictator - see: Carl Schmitt, Dictatorship (Cambridge: Polity Press 2014), 112. In his earlier writings Schmitt had supported this type of dictator, only to go further, with a 'sovereign' one, where the existing constitution was not merely suspended, but abrogated - see: Carl Schmitt, The Concept of the Political (Chicago: University of Chicago Press 1996), 87-88. Schmitt joined the Nazi Party in 1933 (but left it in 1936). Indeed, Schmitt was a great advocate of Thomas Hobbes - Carl Schmitt, The Concept of the Political (Chicago: University of Chicago Press 1996), 65 - but later doubted whether Hobbes had gone far enough in his absolutist sovereign! - see: Carl Schmitt, The Leviathan in the State Theory of Thomas Hobbes: Meaning and Failure in a Political Symbol (Chicago: University of Chicago Press 1996), 65.

${ }^{123}$ Richard Tuck, Hobbes: A Very Short Introduction (Oxford: Oxford University Press 1989), 
why later generations, who were not party to the original covenant, would honour its obligations. ${ }^{124}$ Like Hobbes, Rousseau believed that if the social compact had opponents at the time when it is made, their opposition did not invalidate the contract; it merely prevented them from being included in it, making them foreigners among citizens. For Rousseau, once a state had been instituted, residence constituted consent; to live within its territory was to submit to its sovereignty. ${ }^{125}$ To renounce their obedience, individuals had to leave the state. Alternatively, they would be constrained from acting against the general will: they would be 'forced to be free'. This infamous quote by Rousseau has been widely criticised as being totalitarian. Chapman, however, does acknowledge that Rousseau's use of the word 'free' in this way may appear illiberal to many and especially to those who would maintain freedom means only absence of restraint. But if a person looked at what Rousseau had intended to say, and disregarded his peculiar use of the word 'free', Rousseau neither intended nor achieved subordination of the individual to society. ${ }^{126}$ What was needed was a general recognition or understanding that there would be some form of sanction, that people disobeying the rules would be penalised, in other words that the rules could be enforced. ${ }^{127}$ For Kain, this is certainly not totalitarian - it is not even unusual. ${ }^{128}$ Indeed, without enforcing compliance with the general will, the rule of law would be violated, ${ }^{129}$ in accepting that individuals were above the law. Moreover, Rousseau's community was different from other societies. In it, everyone voted on the laws they were expected to obey. In being forced to obey laws which individuals had given themselves, for Kain, 'the citizens certainly should be considered to be freer than would be the case otherwise'. ${ }^{130}$

Moving away from challenging the alleged absoluteness of the Rousseauian state, the next section of this piece examines the rights and liberties conferred on individuals within it. Rousseau was surely one of the greatest advocates of liberty, dedicating a lengthy discussion of the types of individual freedom in his A Discourse on Inequality. But of course, this was in the state of nature (or at least prior to the pre-political state of nature). It will be recalled, however, that in instituting civil society there was to be no loss of freedom. In addition, in The Social Contract Rousseau famously stated, too, that liberty was one of the greatest goals of legislation. ${ }^{131}$

It was stated above that Rousseau believed in the natural rights of individuals, such as the natural right of self-preservation, freedom from slavery and freedom from want; persons were equal. Like John Locke, Rousseau also propounded the 'essential gifts of nature, such as life and liberty'. Did the natural right to life, for example, endure after the institution of civil society? First, it was noted above that in The Social Contract Rousseau doubted whether a person could relinquish their life to the sovereign, the right being inviolable. But the death penalty could be imposed on opponents of the civil religion, for example. However, capital

\section{7-78.}

${ }^{124}$ Brian Bix, Jurisprudence: Theory and Context $6^{\text {th }}$ ed. (London: Sweet and Maxwell 2012), 110.

${ }^{125}$ Rousseau (n 43) Book IV, Chapter II, 108.

${ }^{126}$ Chapman (n 10) 39.

${ }^{127}$ Mason (n 104) 121-138, 122.

${ }^{128}$ Kain (n 74) 321.

${ }^{129}$ Mason (n 104) 121-138, 123.

${ }^{130}$ Kain (n 74) 321.

${ }^{131}$ Rousseau (n 43) Book II, Chapter XI, 52. 
punishment was certainly not a first resort and was discouraged if someone could safely be left alive, no longer posing a threat to the state. ${ }^{132}$ Thus, Rousseau's defence of the state's use of the death penalty was an extremely limited one. ${ }^{133}$ Indeed, Brettschneider believes that if Rousseau was writing today, he would be categorically opposed to the death penalty; Rousseau had a grudging acceptance of the punishment in his time only because society lacked the infrastructure to keep a person in custody for life. ${ }^{134}$

For criminal conduct deserving of punishment, whether it was the death penalty or not, there had to be a proportion between the harm caused to society and the punishment inflicted on the individual: 'Harshness of punishments is merely a vain expedient dreamed up by small minds to substitute terror for the respect they cannot obtain. ${ }^{135}$ And the use of torture, albeit as a punishment rather than to extract information or a confession, was a sign that the government was weak or lazy. Every wrong-doer could be turned to some good. ${ }^{136}$

In regards to freedom of religion, it will be recalled that the sovereign could prescribe a community faith. The purpose of the civic religion was to increase public spiritedness. For Rousseau, religion controlled a person's prideful tendencies by diverting them away from material interests toward group satisfactions. Without religion a person was likely to be dominated by selfishness. ${ }^{137}$ So the strength of conviction Rousseau showed to opponents of the civil faith - banishment, or even death - was more than merely a consequence of rejecting the state recognised religion: the punishments were for anti-social behaviour, not impiety. ${ }^{138}$ Moreover, there were exceptions to this prescription: a person could also have their own religion; dogmas of this other religion were no concern of others except insofar as they involved morality. ${ }^{139}$

As for freedom of thought, expression and association, it will be recalled that discussions about the general will were proscribed outside of the sovereign assembly, because of the risk that the interests of groups would be incompatible with it. Factions and partial associations were also prohibited more generally. But an outright ban on all groups was not the intention. Expression of the general will be required that no one group had a monopoly of political power and that there would be a sufficient number of groups to ensure diversity of views on the common interest. ${ }^{140}$ This ensured that individuals were adequately informed prior to a collective determination of the general will. In reply, therefore, to the common claim that the general will was merely an expression of totality, Chapman responds:

\footnotetext{
${ }^{132}$ Ibid., Book II, Chapter V, 36.

${ }^{133}$ Corey Brettschneider, 'Rights Within the Social Contract: Rousseau on Punishment' in Austin Sarat, Lawrence Douglas, Martha Merrill Umphrey (eds.), Law as Punishment/Law as Regulation (Redwood City: Stanford University Press 2011), 50-76, 60. See also: Felicity Baker, 'Eternal Vigilance: Rousseau's Death Penalty' in Wokler (n 8) 152-185.

${ }^{134}$ Ibid., 61.

135 Jean-Jacques Rousseau, 'A Discourse on Political Economy’ in Rousseau (n 39) 111-138, 117.

${ }^{136}$ Rousseau (n 43) Book II, Chapter V, 36.

137 Ibid.

${ }^{138}$ Ward (n 73) 101.

${ }^{139}$ Rousseau (n 43) Book IV, Chapter VIII, 136.

${ }^{140}$ Kain (n 74) 320.
} 
'It is not a consensus which may be imposed, which can be described in terms of conformity, or which represents the subordination of individuals to society. Rather it is a dynamic consensus, the validity of which depends on individual autonomy. This form of consensus may hardly be described as an illiberal ideal. Nor can the process by which it may be attained be described as undemocratic. It is thoroughly democratic in its recognition of the value of the contribution which may be made by each and every participant to the expression of the general will., ${ }^{141}$

Freedom of thought and expression were also circumscribed by Rousseau's office of a public censor. But the censor did not pass judgment on the people's opinion; it only declared it. ${ }^{142}$ Indeed, in Rousseau's time many of his works were greeted with outrage and disgust but the suppression of speech was common. In regards to the publication of the Letters from the Mountain, for example, Rousseau described in his autobiographical The Confessions, dating from 1769: 'After [this] seemed to be general astonishment...that such a monster as I could be permitted to breathe. The...Prosecutor General issued a declaration against my book in which it declared in the most outrageous terms that it was unworthy to be burnt by the public hangman. ${ }^{\text {'143 }}$ And openly cited by the clergy, the people 'became absolutely out of control'. From the pulpit, Rousseau was called the Antichrist, and chased in the country as he 'were a were-wolf' ${ }^{144}$ Thus, Rousseau was the victim of shameful public condemnation, but, of course, this did not prevent him from adopting a public censor office for his own civil society. Indeed, the office was an institution that existed in Rousseau's time - Rousseau had had to apply to the office, for example, to allow the importation of The Social Contract by sea to the port of Rouen in $1762 .{ }^{145}$ Obviously, this encounter with the public censor office had not put Rousseau off retaining the institution in his own writings. Moreover, reviewing the office of the public censor from modern eyes, is it really any different from contemporary classifications of films and videos, especially restrictions on children and young people's access to violent and pornographic media? ${ }^{146}$

Unlike John Locke, Rousseau did not propound the natural right to property, since individual property ownership had caused an artificial inequality between people in the state of nature, thus precipitating the need for political society. For Rousseau, the right to property was only conventional and of human institution, ${ }^{147}$ thus it was a civil right. Nevertheless, as a civil right, it was 'the most sacred of all the citizen's rights' ${ }^{148}$ and 'more important in certain respects than Liberty itself' ${ }^{149}$ But Rousseau was keen to emphasise that the right to property was not unlimited, since the maintenance of the state and of the government demanded costs and

\footnotetext{
${ }^{141}$ Chapman (n 10) 83.

${ }^{142}$ Rousseau (n 43), Book IV, Chapter VII, 127.

143 Jean-Jacques Rousseau, The Confessions (London: Penguin Classics 1953), Book XII 1765, 575.

144 Ibid., Book XII 1765, 579.

${ }^{145}$ Ibid., Book XI 1762, 527.

${ }^{146}$ Mads Qvortup, The Political Philosophy of Jean-Jacques Rousseau: The Impossibility of Reason (Manchester: Manchester University Press 2003), 67.

${ }^{147}$ Rousseau (n 40) 128.

148 Jean-Jacques Rousseau, 'A Discourse on Political Economy' in Rousseau (n 39) 111-138, 127.

149 Ibid.
} 
expenditures. ${ }^{150}$ Indeed, assuming the natural right to freedom from want endured after the institution of civil society, public finances were required to fund this freedom. ${ }^{151}$ (As a minimum level of subsistence no-one should have been poor enough to be forced to sell themselves). ${ }^{152}$ Education, especially of children and young people, is a significant aspect of Rousseau's writing - so much so he published a whole book on the topic, Emile, in 1762. ${ }^{153}$ Considerations of education within Rousseau's philosophy are, for reasons of word length, beyond the scope of this article. But, as a human right, Rousseau supported free state education, ${ }^{154}$ which of course had to funded by public taxation.

A key principle of Rousseau's thinking is 'equality', and 'equality of opportunity' in particular. One of the principal items of business for government, therefore, was to prevent extreme inequality of fortunes. ${ }^{155}$ So, in not prohibiting inequality of fortunes per se, individuals were motivated - they were free - to improve themselves financially. Indeed, whilst there was a minimum level of subsistence so that no-one should be poor enough to be forced to sell themselves, public welfare was not to be so high that it disincentivised people from working. ${ }^{156}$ Furthermore, since taxes, for Rousseau, attacked the right to property - and consequently the true foundation of public society ${ }^{157}$ - they were always subject to 'dangerous consequences'. ${ }^{158}$ Taxes must always, therefore, be established with the express consent of the people ${ }^{159}$ and be levied in 'an equitable and truly proportionate way'. ${ }^{160}$ Logically, it was 'unjust and unreasonable' to tax people who had nothing. ${ }^{161}$

Rousseau had an idealised view of liberty in the state of nature, like Locke. But as private property began to feature more prominently in the state of nature, Rousseau believed that people became increasingly hostile towards one another. Civil society was, therefore, necessary, not only to maintain collective protection, but to restrain unfettered individualism. Significant power was vested in Rousseau's sovereign, but individuals enjoyed freedom in seemingly equal measure. Thus far, we have considered the position of Hobbes and Locke on the liberty/security divide, but from the sections above considering Rousseau's power of the state, and the rights enjoyed by its citizens, where is Rousseau positioned on the same divide?

150 Ibid.

${ }^{151}$ Rousseau (n 43) Book II, Chapter XI, 52.

152 Ibid.

${ }^{153}$ It is a surprise to learn, therefore, that, with his lifelong interest in education, Rousseau would abandon his own five children to a public orphanage - see: Rousseau (n 143) Book Eight 1750-1752, 332-333. At the time Rousseau thought he was doing right by his children as a father, in not having the financial means to privately educate them. But with hindsight he came to the realisation that his decision to abandon them had been wrong (333).

${ }^{154}$ Jean-Jacques Rousseau, 'A Discourse on Political Economy' in Rousseau (n 39) 111-138, 126.

${ }^{155}$ Ibid, 127.

156 Ibid.

${ }^{157}$ Ibid., 132.

${ }^{158}$ Ibid., 138.

${ }^{159}$ Ibid.

${ }^{160}$ Ibid., 134.

161 Jean-Jacques Rousseau, 'Considerations on the Government of Poland and on its Projected Reformation' in Rousseau (n 99) 181-265, 236. 
And, unlike Hobbes and Locke, does he provide a (better?) conceptual foundation to counterterror law passed in the UK since 9/11? These questions are considered in the next section.

\section{Rousseau and counter-terror law in the UK since 9/11}

In presenting Rousseauian ideals of the social contract, first, analogies can be drawn with the absolutist state of Hobbes and what may be described here as the hard security end of the division between liberty/security: there was an alienation of a person's rights and their possessions to the sovereign; the sovereign was above the law; the proscription of factions/partial associations; the imposition of a civic religion; and the obligation imposed on individuals to do the sovereign's bidding and to conform to the general will etc. But, at the same time, there are many arguments presented here to draw the sovereign significantly away from totality, in presenting Rousseau's thought more closely to the liberty tradition of Locke. First, assuming individuals freely agreed to join the political community, the social contract afforded them the same freedom they had previously enjoyed in the state of nature. Furthermore, Rousseau's sovereign was the antithesis of tyranny; there was a separation of governmental powers, at least in the division between legislative and administrative functions, together with a respect for the Rule of Law; the sovereign was limited to passing just laws, and the goal of legislation was liberty; forcing individuals to be free was not an attempt to compel state compliance but merely to ensure individuals respected laws, of which they had had direct input; there were periodical reviews of the continuance of government; and equality of opportunity was guaranteed. Indeed, there were rights of individuals. Some rights were natural: life, liberty and the freedoms from slavery and want. And some rights were civil: property, thought, conscience, speech, as well as the rights to (limited) welfare. Following an original aim of this piece, therefore, where on the line between liberty and security can Rousseau be drawn?

In determining Rousseau's place on the spectrum between liberty and security, one approach could be a simple numerical exercise, in merely counting up the number of arguments on either side of the divide and the side with the most arguments wins. But from a libertarian perspective, with a natural antipathy towards the state, especially where individual freedom is being sacrificed, it would be inappropriate to attach equal weight to each argument. Ideologically speaking, like with like is not being compared: the rights of the individual, for example, are far too important to be traded-off against security benefits in equal measure. Indeed, to draw (very loosely) on Immanuel Kant's critique of the utilitarianism of Jeremy Bentham - the latter rejecting natural rights as 'nonsense on stilts', to present a doctrine of legal positivism rather than natural law - then rights, especially human dignity (if indeed this right actually arises in this piece), should not be part of any utilitarian balancing experiment at all. ${ }^{162} \mathrm{But}$, in adopting a Kantian rejection of trading off human dignity against the common good of security, one of the very purposes of this piece - to position Rousseau between the two divides - is avoided. So, to engage in an actual exercise of trading liberty off against security in a Rousseain sense, to fulfil a stated aim of this piece, but still accommodate libertarianism, at least to some degree,

162 To explore these issues in broad terms, as presented here, see, for example: Michael J Sandel, Justice: What's the Right Thing to Do? (London: Penguin 2009), especially 107-108. For a specific reference to Kant, see, for example: Immanuel Kant, Groundwork for the Metaphysics of Morals (Oxford: Oxford World's Classics 2019); for a specific reference to Bentham, see, for example: Jeremy Bentham, An Introduction to the Principles of Morals and Legislation (Mineola: Dover Philosophical Classics 2017). 
which considerations from both camps are to be balanced? and how much weight should be apportioned to each of them?

Naturally, there are a number of caveats to allegations of totalitarianism within Rousseau presented here, pulling his ideas much more towards the liberty side of the divide. But if different weight was being attached to each consideration, to reflect a libertarian scepticism about a balance involving individual freedom, then the alienation of a person's rights and possessions surely overshadows many considerations in support of drawing a much more security orientated approach. So, on this method, for Rousseau, security clearly favours liberty. But, in adopting such an exercise, is a disproportionate voice being given to libertarianism? Hobbes, for example, whilst represented here (for want of a better less liberally skewed term) as a 'securitat', did not have an ideological axe to grind when it came to the state. ${ }^{163}$ For Hobbes, the state was neutral, so he would not have comprehended why liberty was automatically accorded greater importance than security. Has an impasse been reached?

For simplicity, therefore, why not a balance between all the arguments from both sides, each argument being given equal weight? especially since more sophisticated methods such as the ones presented above also have their limitations? (In terms of words, the length of this article is not unlimited, after all.) If it was a simple question, therefore, of which side of the divide outnumbered the other, then the balance for Rousseau must fall more in favour of liberty than security. But the balance is certainly more evenly matched than, say, for Locke.

Having positioned Rousseau on the liberty side of the divide, the next question to be considered is, does he theorise the legislative model of counter-terrorism adopted by the UK since 9/11? It will be recalled that there have been a number of statutory responses in the UK in the last 20 years or so - the Anti-Terrorism, Crime and Security Act 2001, the Prevention of Terrorism Act 2005, the Terrorism Act 2006, the Counter-Terrorism Act 2008, the Terrorism Prevention and Investigations Measures Act 2011, the Counter-Terrorism and Security Act 2015, the Counter-Terrorism and Border Security Act 2019 and now (at the time of writing) the CounterTerrorism and Sentencing Act 2021 - suggestive of a security response at the Hobbesian end of the spectrum. However, there has been a relaxation of counter-terror measures in the UK in favour of liberty over the same period: the abolition of the controversial stop and search power in s.44 of the Terrorism Act 2000, the reduction in the pre-charge detention period from 28 to 14 days, the reform of the indefinite detention of international terror suspects with the introduction of control orders; control orders have themselves been replaced by terrorism prevention and investigation measures (TPIMs). So there has been a shift away from the hard security end of the division. But the gains in freedom have been intermittent and largely cosmetic, so there is still a concentration of state power in the UK in regards to counterterrorism, suggestive of a particular security orientated response on the Hobbesian side of the balance.

An original finding of this article is to position Rousseau somewhere in the middle between the hard security of Hobbes and the soft security of Locke. If Rousseau and counter-terror law in the UK both seem to occupy the middle ground, then surely the UK's counter-terror response must have a conception in Rousseau? However, as Rousseau is apparently closer to Locke than Hobbes, and UK counter-terror law is closer to Hobbes than Locke, then Rousseau must provide only some theoretical justification. Indeed, such a conclusion is not founded on a

163 Tuck (n 123) 85. 
precise science: for one thing, Rousseau's legislative sovereignty is vested in everyone, via an expression of the general will; the legislature in the UK, the Parliament at Westminster in London, is founded on representative democracy, with an overlap between executive and legislative powers, because the Cabinet is drawn from a pool of Members of Parliament (MPs). Parliamentary and Rousseauian sovereignty are not a like-for like comparison. Indeed, in the Rousseauian social contract, all the limitations imposed on the sovereign's power, together with all the liberties enjoyed by the citizen, are calculated here. In comparison, only one element of the state's power in the UK, and its ensuing limitations on liberty, is considered here: that of counter-terror law. Thus, when compared to the whole population of the UK, the effects of this area of law on liberty are minimal, being applied only to the very small number of people suspected of terrorism. Statistically speaking, in London, for example, of those stopped and searched on suspicion of terror activity, as per s.43 of the Terrorism Act 2000, there were only 589 in the year ending March 2020. ${ }^{164}$ Is it right, therefore, to present Rousseau as a conceptor of the UK's counter-terror law when virtually no-one in the country is affected by the breadth of criminalisation in this area? For this reason, the author does not present Rousseau as a definitive theorist for assessing the legislative model of security employed by the UK in recent years. But, as the author is still convinced that Rousseau's writings are a much closer foundation than either those of Hobbes or Locke, the claim that Rousseau still provides some vindication for the UK's response can be asserted.

\section{Conclusion}

Following the terror attacks in America on 11 September 2001, the world community has been (more?) united in its collective attempts to combat terrorism. But these attempts have been hampered by disagreement at international level as to what precisely terrorism means, thus the responsibility for the criminalisation of acts of terror has largely fallen on individual member states. The UK has been keen to move beyond a standard criminal justice response and enact a number of liberty-interfering statutes conferring wide discretion on state authorities to investigate, prosecute and ultimately punish terror orientated crimes.

Social contract theory, especially of the Enlightenment period, is premised on the institution of governmental bodies, principally a sovereign, to oversee collective security. But in a sovereign guaranteeing protection, the freedom that individuals had previously enjoyed in the state of nature must be forfeited, or at least curtailed. The degree to which liberty in this bargain of protection is sacrificed depends upon the social contract theorist under review. For Thomas Hobbes, an absolute sovereign for the maintenance of peace was necessary; following the horrors of the English Civil War a bad government was preferable to no government. For John Locke, however, the transition from the state of nature to a civil society was much more conditional on the guarantee of the natural rights of the individual, to life, liberty and property. But these two writers present relatively predictable outcomes on a divide between liberty and security. Here there has been a much more original examination: to pose similar questions about another Enlightenment social contract theorist, Jean-Jacques Rousseau, who has been neglected by the security discourse. The aim of this piece has been to situate Rousseau on the

${ }^{164}$ Home Office, Operation of Police Powers under the Terrorism Act 2000 and Subsequent Legislation: Arrests, Outcomes, and Stop and Search Great Britain, Financial Year Ending $\begin{array}{lllll}\text { March } & 2020 & 11 & \text { June }\end{array}$ $<$ https://assets.publishing.service.gov.uk/government/uploads/system/uploads/attachment_dat a/file/891341/police-powers-terrorism-mar2020-hosb1520.pdf> last accessed 4 May 2021. 
spectrum between liberty and security and then apply his position to the legislative model of counter-terrorism employed by the UK since 9/11.

Rousseau was born only eight years after Locke's death, in 1712. Uniquely, Rousseau departed significantly from the approaches of Locke, and Hobbes, in instituting the sovereign in the people, not by the people. Thus, there was no need to guarantee citizens a right to resist the sovereign if the latter became a threat to security, since, for Rousseau, the sovereign, being the people, would naturally not harm itself. Indeed, Rousseau foresaw his social contract as guaranteeing collective protection, but at the same time retaining the liberties individuals had previously enjoyed in the state of nature.

Historically, Rousseau has been charged with totalitarianism by Benjamin Constant, for example, and, more recently, by Bertrand Russell and Isaiah Berlin. But, for Chapman, emphasis on Rousseau's work as a source of totalitarian doctrine may have overlooked its contribution to the theory and practice of liberal democracy. And the most original contribution to liberal theory of the $20^{\text {th }}$ century - indeed maybe to the whole of political philosophy of the same period - John Rawls' A Theory of Justice acknowledges the debt it owes to Rousseau. So, as an academic exercise, the categorisation of Rousseau is not without its challenges. This perhaps explains, therefore, why Rousseau's stature in social contract philosophy has been overlooked in theories of security. It is for this reason why the author of this piece has been keen to plot Rousseau on the divide between soft and hard security. Here Rousseau's social contract theory has been classified as being freedom-orientated, though less so than Locke. Thus, his ideals would support a much less strict model of security than Hobbes, for example.

Whilst the UK's legislative approach to counter-terrorism has been reformed on occasions since $9 / 11$ to accommodate a greater respect for individual liberty, such as the abolition of indefinite detention for international terror suspects and the reduction of the pre-charge detention period from 28 to 14 days, this has been infrequent. The number of statutes passed in the UK, as well as the breadth of their criminalisation, support a counter-terror model on the (hard) security side of the spectrum. Between hard and soft security is a position where this piece finds Jean-Jacques Rousseau, too. Rousseau is therefore presented as a conceptor of UK counter-terror law, though his writings suggest a slightly greater respect for liberty than the UK law would allow. Nevertheless, if Rousseau is to be employed in this way, then this formulation of his ideas, from an appreciation of all the rights of his citizen, together with all the limitations imposed on his sovereign's power, must be acknowledged. Counter-terror law, which is certainly draconian in its interferences with individual liberty, only affects a terror suspect, so very few people in the UK are touched by it. In this respect, therefore, freedoms enjoyed by everyone (Rousseau) are being compared with only those suspected of terrorism (UK). Is this a fair comparison? But the aim here is not to present Rousseau, at least not categorically, as a theorist conceptualising counter-terror law: for methodological reasons the aim is merely to determine whether he provides a holistic vindication of the UK's broadly defined security regime. In this, he largely does so. 